\title{
1. Introduction to Liberal Solidarity: The Political Economy of Social Democratic Liberalism
}

Everyone has duties to the community in which alone the free and full development of his personality is possible. United Nations Universal Declaration of Human Rights, Article 29 (1948)

In the first two decades of the twenty-first century the world has entered its greatest political crisis since the Second World War. The Great Crash of 2008 and the COVID-19 pandemic have fractured the world economic system and led to rising swells of populism and nationalism. World trading arrangements have been ruptured. The climate emergency requires immediate coordinated action between capitalist economies - it is irresponsible to suggest that these remedial measures must wait for socialism. Other priorities include the reduction of economic inequality, and the defence of representative democracy and human rights against growing populism and nationalism. There is an urgent need for constitutional reform in several major democracies, including the US and UK. Welfare provision and education need to be extended and greatly improved.

The economic and political ills of the last half century are often put down to the unleashing of capitalism from state controls under the ideological sway of so-called 'neoliberalism'. While the rise of the Chicago-based economics of Milton Friedman and others has much to answer for, this diagnosis is deficient. In fact, the last half century has seen the vast extension and development, not the retreat, of state regulation. In most major developed countries, average taxation levels and welfare expenditures per capita have increased. Chicago economics is real and powerful. It is a formidable ideological force behind financial deregulation and increasing economic inequality. But, as Thomas Piketty has argued, what has happened in recent decades must also in part be put down to the more progressive ideologies losing impetus, and their failure to keep up with the dramatic changes in the modern world. ${ }^{1}$

1 Vogel (1996), Jordana et al. (2011), Siems and Schnyder (2014), Hodgson (2019b, ch. 7), Piketty (2020). 
We need a rethink. We must draw on ideas from the past, as well as developing new ones. I describe the approach outlined in this book as 'liberal solidarity'. It draws from a strong and varied tradition of liberal thinking that connects the advocates of liberté, égalité and fraternité at the time of the French Revolution, including Mary Wollstonecraft, Thomas Paine, Toussaint Louverture, Thomas Jefferson, Wilhelm Humboldt, Benjamin Constant and Germaine de Staël, through nineteenth-century liberal writers such as Alexis de Tocqueville, Harriet Martineau, John Stuart Mill, Frederick Douglass and Thomas Hill Green, to twentieth-century social democratic liberals such as John A. Hobson, Leonard T. Hobhouse, David Lloyd George, John Dewey, John Maynard Keynes, William Beveridge, Michael Polanyi, Karl Popper and Amartya Sen. ${ }^{2}$ Social democratic liberals promote a greater role for the state, in providing welfare, promoting employment and regulating markets. There are also similarities with the solidarisme of Léon Bourgeois and Émile Durkheim, which sought in France a middle ground between socialism and capitalism. ${ }^{3}$ Some core ideas of 'liberal solidarity' are not new. But it needs to be renewed, to face the heightened challenges of the twenty-first century.

All ideologies carry baggage from their past. ${ }^{4}$ Some social democratic parties have strong residues of their previous association with socialism. Many

2 But by the late 1920s the elderly Dewey professed an (unfeasible) socialist rather than a (feasible) social democratic liberalism. Michael Polanyi was a younger brother of the famous Karl Polanyi, the socialist author of The Great Transformation (K. Polanyi 1944).

3 Durkheim is sometimes seen as a champion of 'associationalism', but his position is very different from that of G. D. H. Cole, who Hirst (1994) saw as a pioneering associationalist. Cole $(1917,1920)$ rejected the idea that associations or 'guilds' should have legal autonomy: he saw them as divisions of nationalized industries, and unlike Durkheim he rejected markets (Hodgson, 2019b, pp. 40, 61-2). See also Lippmann's (1922, ch. 19) critique of guild socialism. Associationalism is compatible with liberalism only if it grants legal autonomy and rights to associations, within a market economy.

4 Many so-called progressives excluded women, ethnic minorities or immigrants from their vision of human camaraderie. Unfortunately, just as there are racist and anti-Semitic statements in the writings of Marx and Engels, Hobson is also guilty of anti-Semitism. Several prominent socialists and trade unionists in England held anti-Semitic views. In the US Progressive Era (1890-1930), legislation to bar immigrants from 'inferior races' had wide support, including among Democrats and trade unionists. Supporters of eugenics included the liberals John Maynard Keynes and Walter Lippmann, and the socialists Harold Laski, George Bernard Shaw, and Sidney and Beatrice Webb. Until 1976, social democratic Sweden followed eugenics and was sterilizing people with severe disabilities or deemed insane. See Lippmann (1937, pp. 226, 232), Mitchell (1965), Holmes (1978), Paul (1984), Hodgson (2006b, p. 18), Leonard (2016), Singerman (2016), Cohen and Garrard (2017, pp. 161-2), Virdee (2017). 
left parties include both social democrats and socialists, thus obfuscating their political differences. I argue in this book that it is essential to distinguish social democracy from socialism, and to understand why large-scale socialism has always failed. Some social democrats have never fully assimilated the real-world failure of classical socialism, or its lessons for political and economic policy. ${ }^{5}$

Many social democrats inherited from Fabians and others a technocratic and scientistic vision, where broader moral issues were subdued by technical imperatives. Excessive faith in a technocracy can bring an elitist neglect of social diversity, multiple viewpoints and local knowledge. In an increasingly globalized world, social democracy has faced major challenges in growing migration and in the international hyper-mobility of finance capital.

Social democracy has seen the fracturing of its traditional working-class base, with a decline, in several major countries, in trade union membership. Both the identity and traditional mass base for social democracy have been under challenge for some time. In his plea for a renewed social democratic politics, Tony Judt noted its 'exhausted language'. ${ }^{6}$

For such reasons, we need to consider a new term with fresh ideas, while drawing on the remaining strengths and achievements of social democracy. 'Liberal solidarity' is my answer. To refer to the same approach, I sometimes use the label 'social democratic liberalism' as well.

But if such a doctrine is to prosper, then it must have a clear identity. It must establish its moral appeal and practical relevance. It must define its similarities and differences with other creeds. It must enter into conversation with progressive allies. Where there is sufficient agreement, it must seek to cooperate with these forces on specific issues.

Liberalism teaches that we must cherish liberty and the conditions that promote it. But liberty has different meanings. Liberty is understood here is not simply the (negative) absence of coercion, but the (positive) creation of conditions that allow for the flourishing of every individual and community, including future generations. Among other things, this implies the preservation of our natural environment. As Sen has demonstrated, the flourishing of

5 Socialism, for Owen and Marx, meant the common ownership of the means of production. Although they were instigated by Communist parties, the regimes in Russia from 1917-91, China from 1949 and Eastern Europe from 1948-89 all described themselves as socialist. In terms of ultimate objectives, little difference exists between 'socialism' and 'communism'. It was Lenin, not Marx, who (slightly) distinguished between them, making the former the stage of proletarian power, preceding a utopia of abundance (Hodgson, 2019b, ch. 1).

6 Judt (2010, p. 144). On the history of European social democracy, see Padgett and Paterson (1991), Berman (2006). 
positive liberty is crucial for the economic development of poorer countries. ${ }^{7}$ The question whether this or that industry is publicly or privately owned is secondary to these endeavours. When markets and private ownership can work for the common good, then they should be retained.

\section{LIBERAL SOLIDARITY AND ITS RIVALS}

What is distinctive about liberal solidarity? I emphasize eight points:

1. Liberal solidary views liberty not simply as the absence of coercion, but also as freedom from arbitrary power, with opportunities for personal development. Liberty also relies on inclusive and egalitarian institutions that nurture liberal and cooperative values, to maximize human flourishing. These include the rule of law, with just and equal treatment. ${ }^{8}$

2. Liberal solidary promotes equality of opportunity. This implies the reduction of inequalities in power, wealth and income, and the end of discrimination based on gender, race, religion or sexual orientation. We need to tackle the excessive or inappropriate influence of large corporations on governments, organizations and individuals.

3. Liberal solidarity emphasizes the importance of defending human rights and dignity. These rights include the freedoms of expression, assembly and worship, and freedoms from torture, illegitimate detention or destitution. Liberal solidarity endorses the United Nations Universal Declaration of Human Rights of 1948. This document upholds private property as a basic right. It also stresses our duties to others.

4. Liberal solidary sees private property and markets as necessary, but not sufficient, conditions for freedom, autonomy, democracy and the protection of human rights. Private property rights and markets are essential to devolve legal and other powers to multiple groups, which can counterbalance concentrations of power in the hands of the state. But there are some practical and moral limits to markets. For example, markets for slaves or votes are immoral, and markets for love or trust would degrade what was offered for sale. Private property and markets are also insufficient to preserve freedom, democracy and human rights, because these also depend on moral and cultural commitments that are irreducible to property and contract. Markets are essential, but they are not a panacea.

5. Liberal solidary does not assume that individuals are always self-interested, or exclusively devoted to their own personal satisfaction. A society based

Sen (1999).

8 In this book, 'liberty' and 'freedom' are treated as synonyms. 
largely on self-interest, or on the maximization of pleasure, cannot cohere. Evidence shows that we have the potential to cooperate with others and to act morally by 'doing the right thing', rather than always pursuing our narrow self-interest or pleasure. Hence, in designing policies, liberal solidarity appeals to our moral sentiments, to our sense of duty to others and to the need for cooperation, as well as to our self-interest. Welfare states require pooled resources and shared moral commitments. Solidarity with future generations is important when tackling the climate crisis and the destruction of animal and plant species. They cannot be rectified by policies that rely on self-interest alone. ${ }^{9}$

6. While learning from the failures of large-scale socialism, liberal solidarity understands that the state plays a vital role in governing society, sustaining education and welfare, maintaining law and order, defending its population from harm, constituting the legal frameworks for markets and firms, and enabling economic development. The manner and extent to which the state should intervene in the economy is largely a pragmatic issue. ${ }^{10} \mathrm{But}$ evidence shows that countries with strong welfare states have positive outcomes in terms of health, wellbeing and human flourishing. Rather than the rival dogmas of ubiquitous markets or widespread public ownership, liberal solidarity favours a mixed economy.

7. Liberal solidarity defends representative democracy against those who see it as dispensable. It is also committed to the reform of democratic institutions and to the extension of participation in decision making to some other spheres, particularly in the workplace. But individual rights must be protected against populist abuses of democracy by any nominal majority that threaten to remove them. Further extensions of democracy must be based on evidence of their workability and value.

8. Liberal solidarity is committed to international cooperation, which is essential to deal with pandemics and the climate crisis, to end the destruction of biodiversity on our planet, to help prevent war, to sustain a stable and progressive global politico-economic order, and for other reasons.

The concept of 'liberty' in (1) above is nuanced by the considerations that follow, especially in regard to the rights discussed in (3) and (4). The word 'solidarity' refers to the need for cooperation and our duties to others, as especially indicated in (5) and (8). 'Solidarity' also requires specific distributional

9 On the concept of solidarity, see Habermas (1990), Sangiovanni (2015) and Frega (2019).

10 In this book, unless otherwise indicated, I use the word pragmatic in its colloquial sense, stressing practical efficacy. I am also sympathetic to the (quite different) philosophical pragmatism of C. S. Peirce, J. Dewey, W. James, G. H. Mead and others. 
goals and institutional conditions, as indicated under (2), (4), (6) and (7), to promote equality of opportunity and human flourishing.

Just as socialists often over-emphasize the importance and value of nationalization, a minority of liberals treat markets and privatization as the solution to any problem. These contenders place relatively less stress on the virtues of moral motivation, and on duty and solidarity with others. Their mentors include Jeremy Bentham, Herbert Spencer, Ludwig Mises, Friedrich Hayek, Ayn Rand and Milton Friedman. Their versions of liberalism contrast with the precepts of liberal solidarity. ${ }^{11}$

An aim of this book is to separate the social democratic strand of liberalism that I entitle 'liberal solidarity' from rival brands that emphasize an extreme individualism over human duty and cooperation, prioritize property over other rights, and are disposed towards markets as the solution to seemingly every problem.

But although liberal solidarity contrasts with extreme individualism, they share an opposition to socialism, to the traditional kind of conservatism that defends unwarranted privileges and undermines equal rights, and to all forms of despotism. There is a pentangle of options, where liberal solidarity engages with four major alternatives. Against all these, it upholds fuller notions of human rights, human fulfilment and human need.

The socialist left has traditionally emphasized solidary and cooperation. It is almost as if they have a monopoly over such ideas. This is an illusion. Instead, the defining characteristic of socialism since its inception has been common ownership, typically combined with an aversion to markets, competition and private enterprise. The Concise Oxford English Dictionary defines 'socialism' as the proposal that the 'community as a whole should own and control the means of production, distribution, and exchange'. Experience and analysis show that authoritarian rule, rather than solidarity and cooperation, always flows from attempts to construct socialism on a nationwide scale. Some people advocate a vague socialism, of values or sentiment. But no alternative definition to common ownership has ever become widely established.

The notion of human rights derives from liberal, not socialist, writings. Founding socialists, such as Robert Owen, Karl Marx and Frederick Engels, downplayed all talk of rights. As with the utilitarian philosopher Jeremy Bentham, Owen argued that the guiding principle was the maximization of overall happiness. Owen saw the concepts of liberty and rights as biased towards the individual: he feared that their promotion could undermine social

11 In her book on liberalism, McCloskey (2019) embraced Spencer, Mises, Hayek and Friedman, while eschewing Bentham and Rand. 
cohesion and harmony. He also wanted to abolish lawyers, thus weakening any defence of individual rights through legal processes. ${ }^{12}$

Marx and Engels were also candid about their aims: 'The abolition of bourgeois individuality, bourgeois independence, and bourgeois freedom is undoubtedly aimed at.' Their linking of individuality and freedom with an allegedly doomed 'bourgeois' social class was sufficient for them to overrule any complaint about limitations on freedom in general. Engels described the liberal ideals of equality and human rights as "nothing more than the idealized kingdom of the bourgeoisie'. While supporting the proletariat, they granted no political or legal rights to other social classes. This move was disastrous, especially for those who were to suffer the oppressions of twentieth-century Marxist regimes. ${ }^{13}$

While many socialists have distanced themselves from Marxism, they still have made common ownership a foremost priority. For example, eight years before he became UK Prime Minister, Clement Attlee wrote of the 'evils' of capitalism. Their 'cause is the private ownership of the means of life; the remedy is public ownership'. Like most other socialists, Attlee had a vision of a society planned on rational principles. But all attempts to build such a society - from Russia in 1917 to Venezuela more recently - have led to severe violations of human rights. This is no accident. ${ }^{14}$

To use a Marxist metaphor, the highly centralized economic base leads to a centralized political superstructure, which removes countervailing powers and smothers democracy. It has always happened that way. Yet many continue to express sympathy for large-scale socialist experiments, or they wish to try again in the vain hope that it would work out well, for the first time ever. This time, they say, it will be 'democratic'. But all the evidence and arguments are stacked against them. Democracy cannot survive a huge agglomeration of economic power in the hands of the state.

Because liberalism was in retreat for much of the twentieth century, many liberals have gravitated to parties that describe themselves as socialist. Other liberals have moved towards modern conservatism. Consequently, many people who describe themselves as socialist are closer to what would better be described as social democratic liberalism. If you reject widespread nationalization and central planning, if you embrace markets and a permanent private sector, and if you see human rights and social justice as more important than the issue of public or private ownership, then you are not a socialist, at least as

Owen (1991), Hodgson (2018, pp. 67-77).

Marx (1973, pp. 80-1), Marx and Engels (1962, vol. 2, p. 117).

Attlee (1937, pp. 15-16), Hodgson (2019b, ch. 3). 
the term has been used for most of its history, and is still defined in dictionaries today. Instead, you may be a liberal.

\section{UNATTRIBUTED ACHIEVEMENTS OF SOCIAL DEMOCRATIC LIBERALISM}

In 1933, in the midst of the Great Depression, US President Franklin D. Roosevelt inaugurated his New Deal. It consisted of a series of regulatory reforms and public works programmes, with the aim of stimulating the economy, reducing unemployment and raising standards of welfare. It channelled finance into vital private companies as well as public enterprises. Rural cooperatives were helped with loans. Housing construction was boosted. Systems for universal retirement pensions, unemployment insurance and welfare benefits were instituted. Many communities were provided with electricity for the first time. Income inequality was reduced. This was liberal solidarity in action. ${ }^{15}$

The UK Labour government of 1945-51, with Attlee as Prime Minister, faced the immediate problem of getting the British economy on its feet after the destruction of war. Several industries were nationalized. But the private sector and financial markets remained dominant. Britain remained capitalist. Most of these nationalizations were reversed within 40 years. The first majority Labour government failed to build the foundations of socialism. Its more lasting achievements include extensions of the welfare state and the inauguration of the National Health Service.

In health and welfare, the 1945-51 Labour government built on previous Liberal achievements. The foundations of the UK welfare state were laid down by the Liberal government of 1906-14, which passed reforms to help reduce poverty, and introduced old age pensions, free school meals and national insurance.

As a Liberal Party member, William Beveridge authored a collation government report in 1942 that became the foundation of the post-1945 welfare state. Impelled by a strong vision of social justice, Beveridge proposed a wider system of universal national insurance, conferring benefits to people who were sick, unemployed, retired or widowed. He argued that this system would provide a minimum standard of living 'below which no one should be allowed to fall'. His proposals were developed in conjunction with the plan for a National Health Service. Near-full employment was pivotal to his system of social welfare. He expanded on this in his 1944 book Full Employment

15 The effects of the New Deal still remain controversial among economic historians. There is not the space to evaluate them here. 
in a Free Society. In developing this goal, Beveridge relied explicitly on the policy approach developed by another great member of the Liberal Party John Maynard Keynes. Keynes was instrumental in instating full employment as a major policy goal. In his General Theory of Employment, Interest and Money he provided the theoretical underpinnings of this policy. Public spending could help economies move out of recession. ${ }^{16}$

When the Labour government tackled the problems of poverty, inequality and unrealized human potential, within the actually existing structures of capitalism, it turned to liberal thinkers such as Hobson, Keynes and Beveridge, who had long grappled with these vital policy issues. Peter Clarke thus commented on the Attlee government in his excellent book Liberals and Social Democrats: 'Social democracy had arrived under liberal auspices.' When Labour has acted as a social democratic party, it has often borrowed ideas from liberals. ${ }^{17}$

Sweden provides another pertinent example. Its socialists were typically opposed to employee representation on company boards because it would divide their loyalties and reduce worker opposition to capitalism. Instead, worker representation on company boards was championed by Swedish liberals. The liberal People's Party joined a coalition with the Social Democrats in 1976, and worker representation became law. ${ }^{18}$

Generally, as social democracy has moved away from classical socialism and class-based politics, it has adopted ideas from welfarist liberalism. As Stephen Padgett and William Paterson noted in their historical study, in Europe there has been 'a progressive ideological assimilation between social democracy and liberalism'. ${ }^{19}$

Today, social democratic liberalism is exemplified in the Nordic countries. Although they have high levels of taxation and strong welfare states, they are not socialist. The private sector and financial markets still dominate their economies. There has been significant planning from the centre, but the aim of comprehensive overall control has been abandoned. Instead, markets are used in part as instruments of government economic strategy. The key problem raised by Friedrich Hayek - the impossibility of gathering sufficient knowledge at the centre for effective economic planning - is avoided by the retention of markets and a large private sector, with substantial decentralization and economic freedom. But in the meantime, high taxes and transfers sustain their welfare states. ${ }^{20}$

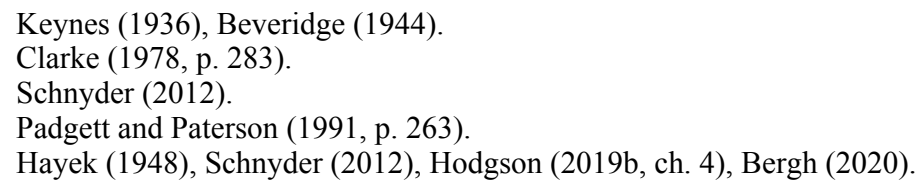


A Hayekian objection to social democracy is that public spending and other state intervention in the economy distorts prices and the important information they carry. Meaningful prices are vital for effective decision making in a complex economy. But markets are not the only information-processing institutions. Firms and other organizations also process information. Market price signals may be less adequate and subject to more noise than many Hayekians assume. If so, there is space for cautious social democratic intervention in a market economy, by using and guiding markets as instruments of change. Even Hayek allowed for substantial welfare intervention by the state. ${ }^{21}$

\section{DISTINGUISHING SOCIAL DEMOCRACY FROM SOCIALISM}

The German Social Democratic Party abandoned the goal of widespread common ownership in 1959. East Germany had been part of the Soviet Bloc for 11 years. The country was split into two parts, on different sides in the Cold War. Support for state ownership might signal a desire for the whole of Germany to be more like its East. At its Bad Godesberg Congress the party declared that it no longer supported a socialist economy dominated by state ownership: 'The Social Democratic Party therefore favours a free market wherever free competition really exists. Where a market is dominated by individuals or groups, however, all manner of steps must be taken to protect freedom in the economic sphere. As much competition as possible - as much planning as necessary.' 22

Crucially, the party moved from a (temporary or permanent) toleration of markets and competition to accepting competitive markets as necessary and desirable, alongside strong public enterprise and state regulation where necessary. In words at least, it adopted social democratic liberalism.

For social democracy to establish its difference with socialism, is not good enough to accept the market or a mixed economy as a temporary expedient, perhaps as a passing staging post in the transition to full-blooded socialism. Following the Bad Godesberg precedent, a modern social democrat must go much further. He or she must make a positive case why markets, competition and a private sector must be permanent. They are indispensable, both for economic efficiency and the preservation of freedom. This defence of a permanent private sector is the acid test.

21 On Hayek's acceptance of some welfare provision see Rodrigues $(2012,2013)$ and Hodgson (2015b, pp. 309-12). Block (1996, p. 365) regretted 'Hayek's interventionistic views'.

22 Taken from http://germanhistorydocs.ghi-dc.org/pdf/eng/Parties\%20WZ\%203 \%20ENG\%20FINAL.pdf. Retrieved 5 November 2019. 
As Judt put it in his defence of social democracy, while socialism is about the overthrow of capitalism, social democracy is a compromise with it: 'it implied the acceptance of capitalism - and parliamentary democracy - as the framework within which the hitherto neglected interests of the population would now be addressed'. ${ }^{23}$

But both opponents and supporters of socialism sometimes obfuscate the difference between socialism and social democracy. Some opponents express their indiscriminate distaste for all forms of state intervention, describing all such action as socialist. Some socialists use the term 'socialism' liberally but without clarity, in attempts to broaden its appeal. Both gambits lead to confusion. ${ }^{24}$

This has happened on both sides of the Atlantic. From 1993 to 1997, Robert Reich was US Secretary of Labor under Bill Clinton. In 2015 he published a well-argued and largely persuasive book entitled Saving Capitalism: For the Many Not the Few. But in 2016 and 2020 he endorsed Bernie Sanders as presidential candidate. Sanders has never expressed a wish to save capitalism. He is a declared socialist. Socialism, in standard dictionaries, means the abolition of private ownership and of capitalism. If Sanders had described himself as a social democrat, then Reich's endorsement would make sense. But there has been no such declaration. Reich wanted to 'save' capitalism, but he supported a candidate who wished to abolish it. How can progressive liberals move forward and gain political power on the basis of such confusion ${ }^{25}$

The UK Labour Party is still entangled on this issue. Before Labour changed Clause Four of its constitution in 1995, its often tokenistic but always explicit ideological commitment to 100 per cent common ownership was retained, while its leaders, when in power, pursued practical policies within a mixed economy. Labour developed a split mentality, celebrating practical social democratic successes while singing 'The Red Flag'. By working within a party that had adopted the classical definition of socialism since its inception, Labour Party revisionists were constantly trying to make the leopard change its spots. They had to deal with Labour's ingrained neglect or distrust of private

23 Judt (2010, p. 229).

24 Crotty (2019) described Keynes as a 'socialist' who was 'against capitalism'. This is difficult to reconcile with several pieces of evidence. Keynes (1972a, pp. 294, 297) wrote that 'I think that capitalism, wisely managed, can probably be made more efficient for attaining economic ends than any alternative system yet in sight', declared that 'the Class war will find me on the side of the educated bourgeoisie' (emphasis in original) and concluded 'the Liberal Party is still the best instrument of future progress'. Keynes wrote to Hayek congratulating him for the critique of socialism in The Road to Serfdom (Hayek, 1944). Keynes (1980, p. 385) saw it as 'a grand book ... Both morally and philosophically I find myself in agreement with virtually the whole of it'.

25 Reich (2015). 
enterprise. At least until the 1980s, Labour was unsure whether economic competition was a good thing. ${ }^{26}$

It took four election defeats and almost 16 years of Conservative government for Labour, under Tony Blair, to revise its aims. The revised constitution of 1995 made a positive case for markets and private enterprise. But, for the first time in its history, the constitution also declared that Labour was a 'socialist' party, which has often been taken as an endorsement of widespread nationalization. This classic socialist view was further promoted when Jeremy Corbyn was elected as leader in 2015, and re-elected in 2016, by large majorities of the membership.

In the following elections for Leader and Deputy Leader of the Party in 2020, all nine candidates - including 'moderates' such as Keir Starmer (who was elected as leader) and Lisa Nandy - felt obliged to sign a declaration in favour of public ownership of all the water companies, of all companies involved in the transmission and distribution of energy, of the entire railway system and of all broadband provision. The declaration stressed 'public ownership', with no promotion of common ownership via worker cooperatives. The declaration did not endorse a mixed economy. ${ }^{27}$

The UK Labour Party seems unable to escape the doctrines of its origin. Its very name connotes the old class-based politics of a former era. Its ideological positions are the inverse of Conservative opponents, who want to privatize instead of to nationalize. Both ideologies are inflexible and unpragmatic. They are unsuited to the dynamic challenges of the modern complex world. ${ }^{28}$

While social democracy is compatible with liberalism, extensive nationalization is not. No country attempting state ownership and control of a large part of its economy has retained democracy and safeguarded human rights. It

26 Toye (2004, p. 91).

27 In addition, all nine candidates agreed to 'oppose profit-making in the justice system' (restricting private agencies from offering legal support), and to 'oppose the outsourcing of local government services' (ending competitive tendering). All leadership candidates pledged to ensure that 'all schools are under local democratic control' (which signals the end of the private sector in schooling). Source: We Own It (2020), which claims that billions of pounds would be saved by public ownership. Much of this evidence is unaudited and in unpublished discussion papers. The predominant focus in these studies is on static efficiency savings. Innovation-related and other possible dynamic efficiency gains of private enterprise are overlooked.

${ }_{28}$ The two-party electoral system partly explains the enduring fudge within the UK Labour Party on whether it is socialist or social democratic, and whether it wants to overthrow or reform capitalism. A similar problem exists, but to a lesser degree, within the US Democratic Party. Two-party systems lead to cohabitations of widely incompatible views. 
is important to place the defence of liberty and human rights ahead of public ownership.

\section{EVEN MARXISTS MUST BE LIBERALS}

Many Marxists have seen democracy and liberty as expendable. In contrast, some intelligent Marxists have declared their support for key liberal ideas and institutions. Hence Norman Geras wrote in 2012:

Unless ... Marxists show themselves willing to engage fully with the intellectual resources of liberalism ... unless a Marxist political theory comes to terms with the truths of liberal political theory, acknowledging the normative force of human rights, the idea of judicial independence and the separation of powers ... insisting on free elections and an untrammelled freedom of speech and opinion, understanding the virtues of political pluralism ... Marxism as a political movement might as well shut up shop. ${ }^{29}$

Echoing these sentiments in their powerful critique of Corbyn's politics, Matt Bolton and Frederick Harry Pitts saw liberalism as a necessary 'prerequisite for any future emancipatory project'. They concluded: 'Liberalism is the sea in which socialists in capitalist democracies swim.' ${ }^{30}$

But these Marxists need to be persuaded that, despite their intentions, the hidden logic of their own position is to undermine the foundations of liberty and democracy. As noted above, a complete concentration of political and economic power in the hands of the state, which Marx and Engels advocated with enthusiasm, always leads to despotism. There have been no exceptions. The centralizing economic project within Marxism and state socialism is ultimately incompatible with liberalism and democracy. Accordingly, there must be a permanent mixed economy with a large private sector with firms that are free to trade on markets.

There is a fundamental difference between the liberal and socialist projects. Many socialists eschew private ownership and markets. Marx and Engels wanted to abolish them entirely. Similarly, Owen opposed all private property. The UK Labour Party's version of Clause Four from 1918 to 1995 called for the 'common ownership of the means of production, distribution and exchange', which allowed for no exceptions. Traditionally, socialism has been intolerant of a capitalist private sector, combining this with its widespread 'agoraphobia' (fear of markets). ${ }^{31}$ 
By contrast, liberalism is pluralist and more tolerant. It supports predominant private ownership and a market economy, partly because that enables a devolution of power, and it allows experimentation with different forms of ownership and organization. Many liberals have expressed enthusiasm for worker cooperatives. Liberal solidarity also proposes significant but selective state intervention in the economy, including a strong welfare state. The pluralist framework of liberal capitalism allows for such experimentation. By contrast, socialism has a history of intolerance of markets and private enterprise.

Liberal solidarity rejects the 'agoraphobic' view that markets are always deleterious and state intervention is always superior. It also discards the 'kratophobic' (fearing government or the state) views of libertarians who always find fault with state intervention and overlook the limits of markets. Liberal solidarity is pluralist and pragmatic.

But basic liberal rights and values are paramount. They sustain a framework within which diverse views and cultures may co-exist. This does not amount to a cultural relativism, where one set of moral values is deemed as good as another. As Francis Fukuyama put it: 'Liberal democracy has its own culture, which must be held in higher esteem than cultures rejecting democracy's values.' Liberal values are supreme. ${ }^{32}$

\section{THE INCOMPATIBILITY OF LIBERALISM WITH LARGE-SCALE SOCIALISM}

Liberalism is compatible with modern social democracy, but not with large-scale socialism. Despite the arguments above, some liberals have tried to reconcile liberalism with socialism.

John Stuart Mill saw both positives and negatives in socialism. He ended up supporting worker cooperatives and some experimentation with public enterprise. But he defended economic competition and he never embraced large-scale socialism or comprehensive economic planning. His liberalism remained intact. ${ }^{33}$

Hobson left the UK Liberal Party in 1916 over its war policy and later joined with Labour. But, like Mill, Hobson never embraced socialism wholesale. Instead he advocated a permanent mixed economy, with significant public ownership. He argued 'for a limited as against a complete socialism'. Although he was influenced by socialism, he was never a socialist in the sense of Owen or Marx. In the Labour Party he 'never felt quite at home in a body governed

32 Fukuyama (2019, p. 166). See Nussbaum (1992), Zechenter (1997) and Hodgson (2018, ch. 8) for critiques of cultural relativism.

33 Mill (1909, pp. 209-17, 792; 2009 [1879], pp. 221-79). 
by trade union members and their finance, and intellectually by full-blooded Socialists'. Instead of pursuing classical socialism, Hobson tried to build bridges between (what later came to be described as) social democracy and liberalism. $^{34}$

Dewey ended up in a different place. 'By the end of the twenties John Dewey would admit, if pressed, that he was a socialist.' He was then in his seventies. In the 1932 US Presential elections he backed Norman Thomas, the Socialist Party candidate, against Herbert Hoover and Franklin Roosevelt. Thomas advocated 'the social ownership of land, natural resources and the principal means of production'. By 1934 Dewey was criticizing Roosevelt for bolstering the capitalist system. For Dewey at that time, there was 'no halfway house' between capitalism and socialism. He called for the comprehensive 'socialization' of natural resources, banking, natural monopolies, public utilities, transportation and communication. Democracy can only be restored if the people as a whole 'own and control the land, the banks, the producing and distributing agencies of the nation'. Roosevelt's social democratic compromise with capitalism was rejected. ${ }^{35}$

Dewey remained a strong defender of human rights and freedoms, but he sustained no sturdy defence of private property. Hence his liberalism was an unstable chair, missing one leg. He was aware of the tyrannical legacy of large-scale socialism in Russia, and like many others he attempted to offer a solution to that problem. This lay in an extensive participatory democracy within a socialist economy. His ideas in this area, as discussed further in Chapter 9, have proved enormously influential.

Dewey's proposed socialist democracy depended on shared knowledge: 'since democracy stands in principle for free interchange, for social continuity', knowledge must be widely available to others. He argued that 'the many' must 'have the ability to judge of the bearing of the knowledge supplied by others upon common concerns'. This set a very high bar for his socialist democracy. Experience has punctured such democratic optimism. Dewey was right to suggest that 'knowledge is a function of association and communication', but this does not imply that much knowledge can be readily shared. ${ }^{36}$

Dewey was vague about the detailed organizational mechanisms of knowledge interchange and of participation in control. He imagined a 'social organization that will encourage the socialized extension of intelligence ... in which the new forces of productivity are coöperatively controlled'. Frank Knight 
described Dewey's conception of knowledge as a 'vague mystical conception ... of "shared life" or "shared experience" ... a kind of intellectualized gregariousness'. Dewey, one of the greatest philosophers of practice and process, offered much less in terms of practical detail. ${ }^{37}$

Dewey had argued at length that knowledge was rooted in practice and embedded in habits. But he did not draw the logical conclusion that this placed severe limits on its transferability. In any economy, a division of knowledge parallels its division of labour. Dewey underestimated the tacitness, embeddedness, dispersion and complexity of knowledge. Today there is much evidence (see Chapter 9) on the limits of participatory democracy - on which Dewey placed so much faith. ${ }^{38}$

Like many others, Dewey thought that large-scale socialism could co-exist with extended and meaningful democracy. But socialism is more than a matter of good intentions. Any concentration of ownership in the hands of the state - which Dewey advocated - creates a concentration of power at the centre. Attempts to decentralize and disperse that power can always be countered or reversed by the collectivist state. There is no countervailing power that can prevent it from doing so. That is why all experiments with large-scale socialism, from Russia to Venezuela, have become dictatorships. Dewey was chasing a chimera. Liberalism is incompatible with large-scale socialism. ${ }^{39}$

Particularly in US politics, Dewey's influence has been enormous. Much of this is positive. But on the negative side it has fostered delusions about the possibility of a post-capitalist and socialist liberalism. This delusion lingers on, particularly among Anglophone liberals. By contrast, while liberals and socialists can join forces on issues where they agree, there is a clear doctrinal division between liberalism and large-scale socialism. They are mutually exclusive. On the other hand, the small-scale socialism of independent worker-owned cooperatives, within a market economy, is entirely compatible with liberalism. John Stuart Mill and other liberals have advocated such a model.

\section{THE ARGUMENT IN THIS BOOK}

Modern complex societies comprise institutional subsystems of (a) production and distribution, (b) government, (c) law, (d) science and (e) civil society. Deweyian liberals and democratic socialists propose that all five subsystems can be managed by democratic processes. In fact, for reasons discussed in this

\footnotetext{
Dewey (1935, pp. 53-4), Knight (1936, p. 230), Eldridge (1996).

Dewey (1922), Hayek (1948), Polanyi (1967).

39 Reinhold Niebuhr was another influential US liberal who was a socialist in the 1930s. But unlike Dewey, Niebuhr renounced socialism in the 1940s.
} 
book, democracy can play no more than a small - but nevertheless important part in (a), (b) and (e). Democracy in (c) can threaten justice and rights. In (d) democracy should be highly limited. You cannot do science by votes. ${ }^{40}$

State socialists elevate state administration in all five areas. I have argued elsewhere that this is a road to despotism. Market fundamentalists assume that market mechanisms should be sovereign in all five areas, or that they should all be treated as if they were markets. I counter this view in this book. Markets and private property are essential for innovation, local adaptation and countervailing economic power in (a), but even here there is a role of state administration and some workplace democracy. The perspective of liberal solidarity is for a pluralist combination of different regulatory mechanisms, including markets, administration, and democracy. ${ }^{41}$

As well as charting the differences between liberal solidarity and socialism, it is crucial to distinguish different strands with liberalism itself. This is one of the major tasks in Chapter 2. Here liberal solidarity comes into confrontation with what might be called 'neoliberalism', although that term has become widely abused, as noted in this chapter.

Too often the word 'individualism' is given solely negative connotations. But, as argued in Chapter 3, several important human rights apply to individuals, in part to protect them against powerful organizations that may abuse their rights. Individual dignity is likewise important. We should not throw out individual rights or dignity with the ultra-individualist bathwater.

Chapter 4 turns at first to the meaning of liberty. The idea of liberty as the absence of coercion is contrasted with a more fruitful emphasis on opportunity and development. A view of liberty that stresses individual education and development has a strong pedigree in the history of liberalism, dating back to Thomas Jefferson and Wilhelm Humboldt. ${ }^{42}$ Following Immanuel Kant and others, the concepts of autonomy and freedom of agency are also explored, leading to a wider discussion of human needs.

Chapter 5 is the longest in the book. It argues that Jeremy Bentham's utilitarianism, while it has impelled several major reforms, has also had strong negative effects. Benthamism, as Keynes put it in 1938, is 'the worm that is gnawing at the insides of our civilization'. ${ }^{43}$ Its assumption that individuals

\footnotetext{
40 On science and democracy, see Polanyi (1962) and Kitcher (2011b).

On state socialism, see Hodgson (2019c).

42 See, for example, Jefferson $(1993$, pp. 77, 197) for his stress on the connection between education and liberty. Boyd (1967, p. 188) edited Jefferson's papers and wrote: 'Education in [Jefferson's] Empire of Liberty was of utmost importance ... Jefferson envisaged a system of education ... to give every individual the privilege of unlimited opportunities for development.'

43 Keynes (1972b, p. 445).
} 
are no more than pleasure seekers undermines the importance of moral motivation and integrity. Yet Benthamite utilitarianism has had a huge influence not only on liberalism, but also on socialism and mainstream economics. The chapter argues for a root and branch reform of economics and liberal thought, to re-establish the importance of moral motivation, both in understanding socio-economic reality and in policy design.

Against the fiction of the utility-maximizing individual, this book stresses the importance of understanding human nature, how it evolved, and how it is guided and affected by our social environment. This is the focus in Chapter 6 , which considers the evolution of our capacity for moral judgment. While evolutionary theory and outcomes cannot justify particular ethical views, they can give some guidance about what works. If particular propositions about human nature lack empirical support and robust evolutionary explanation, then they must be rejected. On these grounds the proposition that humans are entirely self-interested is refuted. The chapter also uses evolutionary theory to criticize the rebuttals of altruism by Ayn Rand and Friedrich Hayek.

Chapters 7 and 8 are concerned with markets. Chapter 7 addresses their moral limits. It is argued that some objections to commodification stem from economic inequality rather than markets as such. But there are still moral limits to some markets. Chapter 8 focuses on the widespread use of market and commercial terminology to describe non-market phenomena. It is proposed that such usages are not innocent: they can have deleterious practical consequences. Consequently, liberal solidarity recognizes the crucial differences between markets and other systems, and it does not reduce all human engagement to matters of contract. A liberal society depends vitally on other forms of social order and adaptation, as well as on markets.

Chapter 9 defends representative democracy, and, where feasible, some extension of democratic involvement into other spheres of life. But many enthusiasts for direct or deliberative democracy are seemingly unaware of their limits and dangers. It is impossible to democratize everything. Pressing for this could lead to a counter-reaction that threatens democracy itself. While liberal solidarity is devoted to representative democracy, it does not treat democracy as a panacea. Extensions of democracy must be evidence based.

Chapter 10 addresses the climate crisis. It contests the idea that system change from capitalism to socialism is necessary to deal with this urgent problem. Not only is this claim deeply flawed, but also it diverts attention from dealing with this crisis, here and now. Accordingly, liberal solidarity 
prioritizes the problem of global warming but insists that it can and must be rectified by restructuring rather than replacing capitalism. ${ }^{44}$

Chapter 11 concludes the book. Much of this chapter highlights the problem of economic inequality and considers some remedial policies. The reduction of economic inequality is central to liberal solidarity. There is a short general conclusion, which looks briefly at future prospects.

Some areas, such as internationalism, immigration, national identity and citizenship, are not discussed at any length in this book. This does not mean that these issues are unimportant. Instead, the focus is on some principal issues of dispute between liberal solidarity and its rivals. One important debate is between liberal solidarity and contrasting liberal doctrines, from Bentham to Chicago. Another rivalry is between liberal solidarity and socialism. Issues are chosen to illuminate the points of difference and agreement.

Globalization is not analyzed here in depth. But it is taken for granted that liberal solidarity must transcend national boundaries and address the disadvantages and disruptions of globalization, as well as its benefits. Liberal solidarity has an internationalist and inclusive vision.

Overall, the thrust of the argument is for experimentalism, recognizing the evolutionary processes that have transformed our species in the past, and are still present in the evolution of cultures and organizations today. Evolutionary thinking is a resource for the development of liberal philosophy and practice. ${ }^{45}$

This book builds on pragmatic and evolutionary theories of morality. At the end of the nineteenth century, William James, Thorstein Veblen and John Dewey, among others, understood the dramatic implications of Darwinism for philosophy and the social sciences, as well of course for biology. As Darwin had pointed out in his Descent of Man, morality was an evolved human attribute, honed by natural selection. Second, as James explored in his psychology, evolution provided a framework to understand the interplay between inherited dispositions (instincts) and learned capabilities (habits) - an approach that undermines the static preference functions adopted by economists. Third, evolution meant the adoption of a processual understanding of human action, always adapting to ongoing changes and without any final end - thus under-

44 Note that 'capitalism' refers to a type of economic system and not to an ideology. See Hodgson (2015b, pp. 20, 59-62, 252-7, 385-6) for a definition of capitalism (accenting private enterprise, financial and other markets, and the widespread use of the employment relationship) and for a rebuttal of the idea that it is an ideology. By contrast, in common usage, 'socialism' can refer to a type of economic system (with common ownership) and to an ideology (that promotes common ownership).

45 Evolution can mean many things. Here the focus is on processes of change in populations of varied entities, where selection changes the composition of that population and individual entities develop as well (Hodgson and Knudsen, 2010). 
mining the utilitarian separation of means from ends and its commitment to an ultimate equilibrium. Generally, individuals should not be taken as given. They too are part of the evolutionary story. ${ }^{46}$

Evolution does not imply the inevitability of progress. As Darwin noted wryly: 'we are apt to look at progress as the normal rule in human society; but history refutes this'. ${ }^{47}$ As noted above, we are in an era when basic liberal and democratic institutions are under threat. No complacency is implied or intended. We have to act, calling on evidence and experience, both to defend and to build anew.

46 Darwin (1871), James (1890), Veblen (1898, 1909), Dewey (1910, 1922, 1938, 1939), Degler (1991), Hodgson (2004a).

47 Darwin (1871, vol. 1, p. 166). 